\title{
Genetic Variation of the Y Chromosome in Chibcha-Speaking Amerindians of Costa Rica and Panama
}

\author{
EDWARD A. RUIZ-NARVÁZZ ${ }^{12}$ FABRICIO R. SANTOS, ' DENISE R. CARVALHO-SILVA." \\ JORGE AZOFEIFA.' RAMIRO BARRANTES,' AND SERGIO D. J. PENA'
}

\begin{abstract}
Genetic variation of the $Y$ chromosome in five Chibchan tribes (Bribri, Cabecar, Guaymi, Huetar, and Teribe) of Costa Rica and Panama was analyzed using six microsalellite loci (DYS19, DYS389A, DYS389B, DYS390, DYS391, and DYS393), the Y-chromosome-specific alphoid system (ah), the Y-chromosome Alu polymorphism (YAP), and a specific preColumbian transition $(C \rightarrow T)$ (M3 marker) in the DYS 199 locus that defines the Q-M3 haplogroup. Thirty-nine haplotypes were found, resulting in a haplotype diversity of 0.937 . The Huetar were the most diverse tribe, probabiy because of their high levels of interethnic admixture. A candidate founder Y-chromosome haplotype was identified (15.1\% of Chibchan chromosomes), with the following constitution: YAP - DYS $199^{*} T$, ah-[f, DYS $/ 9^{*} / 3$, DYS389A*17, DYS389B*I0, DYS390*24, DYS391*10, and DYS393*I3. This haplotype is the same as the one described previously as one of the most frequent founder patemal lineages in native American populations. Analysis of molecular variance indicated that the between-population variation was smaller than the within-population variation, and the comparison with mtDNA restriction data showed no evidence of differential structuring between maternally and patemally inherited genes in the Chibchan populations. The mismatch-distribution approach indicated estimated coalescence times of the $Y$ chromosomes of the Q-M3 haplogroup of 3,113 and 13,243 years before present; for the mtDNA-restriction haplotypes the estimated coalescence time was between 7,452 and 9,834 years before present. These results are compatible with the suggested time for the origin of the Chibchan group based on archeological, linguistic, and genetic evidence.
\end{abstract}

The $\mathrm{Y}$ chromosome is the male counterpart of mtDNA, and as such is a tool for evolutionary studies. Its nonnecombining portion, known as NRY, is haploid and

\footnotetext{
'Instituso de Investigaciones en Salud (INISA) and Escucla de Biologia, Universidad de Costa Rica, San lose, Coser Rica.

${ }^{2}$ Department of Nutrition and Department of Epidemiology. Harvard School of Public Health, 665 Huntington Ave, Boston, MA 02115.

${ }^{3}$ Depertamento de Bioquétrica e Imunologia, Universidade Federd de Minas Gerais, Belo Horizonte, Minas Gerais, Brazi!.
}

Human Biology, Febnuary 2005, v. 77, no. 1, pp. 71. 91.

Copyright os 2005 Wayne State Uniwersity Press, Detroil, Michigan 48201-1309

KEY WORDS: CHIBCHAN TRIBES, BRIBRI, CABECAR, GLAYM, HUETAR, TERIBE, Y CHRO MOSOME, MICROSATEI.LTE LOC, GENE DIVERSTTY, MTONA, DVS19, DYS389A, DYS389B, DYS390, DYS391, DYS393, DYS199, ALPHOID SYSTEM, AlU POLYMORPHISM, COSTA RICA, PANAMA. 


\section{2 / RUIZ-NARVÁEZ ET AL.}

is inherited patrilineally. The NRY embraces all of the $Y$ chromosome except the pseudcautosomal regions, which are homologous to and undergo normal recombination with the $\mathrm{X}$ chromosome (Muller and Schempp 1982; Freije et al. 1992). Therefore the NRY depicts, to a good extent, the evolution of a genomic region affected mainly by mutation pressure and male-limited mechanisms of population structure, thus allowing researchers to estimate divergence times and relative contributions of males and females (mtDNA) to gene pools and to detect some demographic events molding contemporary male population stnuctures (Jobling and Tyler-Smith 1995). The first studies of variation of the Y chromosome in Amerindians showed a major paternal haplotype (Pena et al. 1995; F. R. Santos et al. 1995a, 1996; Underhill et al. 1996) possibly related to a major migration into the Americas from central Siberia (F. R. Santos et al. 1999; Karafet et al. 1999).

The Chibcha-speaking groups inhabit most of the Intermediate Zone (lower Central America and northern South America), and they include most of the languages (24 out of 32) of this area (Constenla-Umaña 199I). There is convincing evidence of continuous occupation of the lower Central American region for as long as 10,000 years (Cooke and Ranere 1992). Chipped-stone spear points used by hunters of the Pleistocene megafauna 10,000-12,000 years ago have been discovered in paleo-Indian sites in the Atlantic Highlands of Costa Rica and in Madden Lake near the Panama Canal (Abel 1981), and evidence of early phases of sedentary horticulture in central Panama can be traced to 5,000 B.C. (Cooke and Ranere 1992). However, the relationship between the original colonizers of Central America and the people who resided in this region at the time of European contact (approximately A.D. 1,500) is unclear. Linguistic reconstruction, using the theory of linguistic affinity decay, shows that Central American Chibchan languages, both those still extant and those extinct since the Colonial Period, can be traced to a common linguistic ancestor, perhaps dating to 6,0008,000 years ago (Constenla-Umaña 1991). Because it is customary to seale linguistic affinity based on the calibrated decay rate for written European languages (Greenberg 1987), some questions remain about the accuracy of linguistic dating for these purely verbal languages. On the other hand, genetic studies using classical autosomal markers have suggested a range of 7,000-10,000 years before present for the origin of the Chibchan group (Barrantes et al. 1990).

In this study we characterize Y-chromosome variation in Chibchan populations, considering the process of microdifferentiation among the screened tribes. Because the demographic histories of males and females may be different, we compare the results with earlier findings based on mtDNA data (M. Santos et al. 1994; Torroni et al. 1994) and estimate coalescence times for both genetic systems.

\section{Materials and Methods}

Study Population. Blood samples from individuals belonging to five Chibchan tribal groups of lower Central America were collected at seven localities 


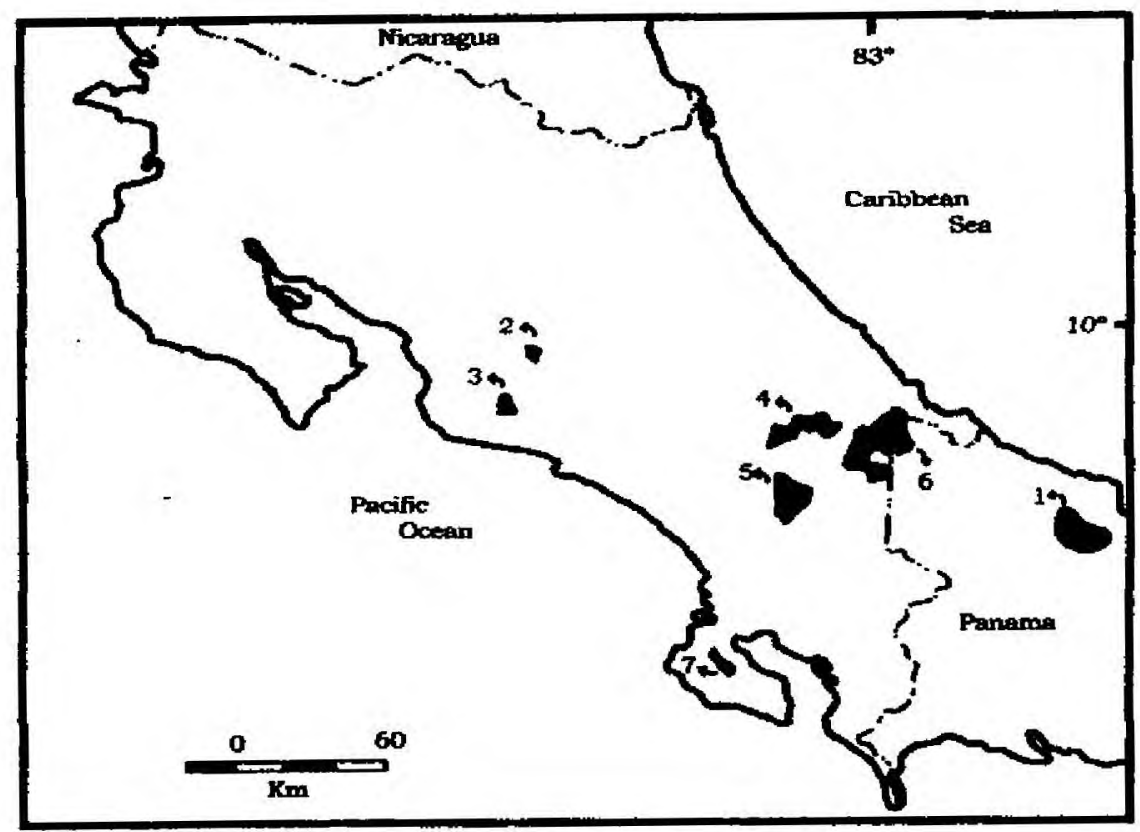

Figure 1. Geographic location in Costa Rica and Panama of the populations or tribes sereened: (1) Sieyik Teribe, (2) Quitirrisi Hoetar. (3) Zapaton Huetar, (4) Alto Telire Cabecar. (5) Ujarras Cabecar, (6) Mojoncito Bribri, (7) Osa Guaymi.

between 1986 and 1998. All these individuals have been typed for classical markers (Barrantes et al. 1990; M. Santos et al. 1994), and those bearing alleles that could be clearly attributed to admixture with non-Amerindians were removed from the sample. Not all non-Amerindian ancestry is detectable in this fashion; thenefore we also removed all individuals who admitted European or African ancestry, regardless of whether it was genetically evident. Although this strategy of sample selection does not completely remove the effects of more ancient gene flow from non-Amerindian groups, we think that we have probably attained a high degree of depuration, given the fact that admixture seems to have increased in the 20th century.

Ninety-three unrelated samples were obtained and classified according to demographic and genealogical studies, as follows (Figure 1): Bribri $(n=14)$, from Mojoncito in the lowlands of the Atlantic side of the Talamanca Cordillera (Talamanca); Cabecar ( $n=15$ ), from Alto Teline in the highlands of Talamanca; 13 males from Ujarras, on the Pacific side of Talamanca; Guaymi $(n=8)$, from Osa; Huetar $(n=13)$, from Quitirisi; 15 males from Zapaton; and Teribe $(n=15)$, from Sieyik (Panama). 


\section{4 / RUIZ-NARYÁEZ ET AL.}

DNA was extracted from peripheral whole blood either with phenol-chloroform (Hermann and Frischauf 1987) or with NaCl (Miller et al. 1988).

Y-Chromosome Polymorphisms. Nine polymorphic markers were screened. The Y-chromosome Alu polymorphic element (YAP) was typed according to the method of Hammer and Horai (1995). The polymorphic $\mathrm{C} \rightarrow \mathrm{T}$ transition (M3 marker) in the DYS199 locus (Underhill et al. 1996), which defines the Q-M3 haplogroup, was typed using a PCR RFLP method using the Mfel restriction enzyme (F. R. Santos et al. 1999). The Y-chromosome-specific ah system was typed according to the method of F. R. Santos et al. (1995b). The tetranucleotide microsatellites DYS19, DYS389A, DYS389B, DYS390, DYS391, and DYS393 were scored and designated by the number of repeats according to the method of Kayser et al. (1997). Naming of the Y-chromosome haplogroups was based on the $\mathrm{Y}$ Chromosome Consortium (2002) nomenclature.

Statistical Analysis The intrapopulation variability, measured through gene and haplotype frequencies and diversity indexes, and the interpopulation genetic differentiation index among the Chibchan tribes were calculated using the Arlequin software (Schneider et al, 1997). For the interpopulation genetic differentiation index, two methods were used: (1) the exact test of population differentiation (Raymond and Rousset 1995), to determine whether significant differences in allele frequencies exist among the Central Amerindian groups, and (2) the analysis of molecular variance (AMOVA) (Excoffier et al. 1992), which takes into account the information on the allelic content of haplotypes and their frequencies. To evaluate a possible difference in the genetic structure at the paternal and maternal levels, we compared mtDNA restriction data to the Y-chromosome data for the following groups: Boruca $(n=14)$, Bribri/Cabecar $(n=20)$, Guatuso $(n=18)$, Guaymi $(n=16)$, Teribe $(n=20)$, and Kuna $(n=16)$ (Torroni et al. 1993, 1994).

Two estimates of fixation indexes that are especially suitable for studies with microsatellites (Slatkin 1995) were computed: $F_{S T}$ (which counts the number of differences between two haplotypes) and $R_{5 T}$ (which counts the sum of the squared number of repeat differences between two haplotypes). The statistical significance of these values was evaluated using a random permutation test (Excoffier et at. 1992).

We also estimated genetic distances between tribes using the squared number of repeat differences between haplotypes, corrected by the average intrapopulation distance among haplotypes. To have a broader perspective of the place of the Chibcha-speaking populations in the context of other native tribes, we used published microsatellite data of the Cayapa (tropical forests of Fcuador), Tayacaja (Peruvian Andes), Arequipa (Peruvian Andes), Gaviao (Brazilian Amazonia), Ticuna (Brazilian Amazonia) (Tarazona-Santos et al. 2001), and Inuit (southwestem Greenland) (Kayser et al. 2001) to draw a neighbor-joining tree 
(Saitou and Nei 1987) using the Neighbor software of the PHYLIP package (Fëlsenstein 1995).

The mismatch-distribution approach (Rogers and Harpending 1992; Rogers 1995) was used to estimate the coalescence time of the $Y$ chromosomes of the Q-M3 haplogroup in the Chibchan tribes. Mismatch distribution refers to the pairwise count of mutations between all pairs of individuals within a population, and it is one-wave shaped when the coalescence events are concentrated in a narrow interval of time (e.g., a demographic expansion or fixation of a haplotype). This distribution is defined for the parameter $\tau=2 \mu_{t} t$, which measures the time of coalescence in units of $1 / 2 \mu_{t}$ generations, where $\mu_{r}$ is the tolal mutation rate within the studied genomic region (Rogers 1995). This method was originally developed based on the model of infinite sites (Kimura and Crow 1964), an assumption that is not suitable for microsatellite loci. Because the number of mutations in microsatellites seems to follow a stepwise mutation model described by Ohta and Kimura (1973), we used an approximation according to Chakraborty and Nei (1976):

$\delta_{d}=\frac{\left(4 N_{e} \mu\right)^{2}}{1+8 N_{e} \mu}+\frac{d\left(I+4 N_{e} \mu\right)}{\left(I+8 N_{e} \mu\right)^{1 / 2}}$

where $\delta_{d}$ is the expected number of mutations between two alleles that differ for $d$ repeats. The parameter $4 N_{\varepsilon} \mu$ (four times the effective population size times the mutation rate) for each microsatellite was estimated using a likelihood approach and the MISAT software (Nielsen 1997) with 1,000,000 runs. Two different mutation rates were used: (1) $3.17 \times 10^{-3}$ per locus per generation, estimated using 4,999 male germ-line transmission events (Kayser et al. 2000), and (2) an effective mutation rate of $6.90 \times 10^{-4}$ per locus per generation, estimated using microsatellite variation within Y-chromosome haplogroups in populations with known short-term histories (Zhivotovsky et al. 2004).

The variance $\left(S_{r}^{2}\right)$ of the estimated coalescence time was approximated as the variance of the ratio of two random variables (generation length and mutation rate), according to the following formula:

$S_{i}^{2}=\left(\frac{\tau}{12}\right)^{2}\left(\frac{S_{g}^{2}}{\mu^{2}}+\frac{g^{2} S_{\mu}^{2}}{\mu^{4}}\right)$

where $S_{\mu}^{2}$ is the variance of the mutation rate based on Kayser et al. (2000) and Zhivotovsky et al. (2004), $g$ is the generation length in years, and $S_{g}^{2}$ is the estimated variance using data from Neel and Weiss (1975). Coalescence time was log-transformed to estimate $95 \%$ confidence intervals. If we define $h(t)=\log (t)$, then, based on the Delta method, a 95\% confidence interval (CI) around $t$ can be estimated as 
76 / RUIZ-NARVÁEZ ET AL.

$\left.95 \% \mathrm{CI}=\exp \mid h(t) \pm 1.96 h^{\prime}(t) S_{l}\right]$

where $t$ is the estimated coalescence time.

Because the mismatch-distribution approach has not been applied to microsatellite haplotype data, we also estimated the coalescence time of the Y chromosomes of the Q-M3 haplogroup in Chibchan uribes, assuming that under stepwise mutations the total squared difference $\left(\Sigma d^{2}\right)$ (Goldstein et al. 1995) in allele size among all current chromosomes is an estimate of $2 \mu_{r}$.

The mismatch-distribution method was also applied to the mtDNA restriction data of haplogroup $A(n=75)$, because it includes almost $70 \%$ of the Chibchan mtDNA haplotypes (Tornoni et al. 1994). The total mutation rate of the mtDNA restriction haplotypes was estimated using the formula

$\mu_{h}=2 \mu k$

(Nei and Tajima 1981), where $2 \mu$ is the divergence rate per nucleotide and $k$ is the number of nucleotides embraced by the restriction sites. Torroni et al. (1994) estimated a divergence rate per nucleotide between $0.022 \%$ and $0.029 \%$ per 10,000 years. They studied 111 restriction sites that covered approximately 2,900 nucleotides. Therefore a total mutation rate, assuming 27 years per generation (Neel and Weiss 1975), between $1.72 \times 10^{-3}$ and $2.27 \times 10^{-3}$ per generation was calculated. Confidence intervals were estimated as previously explained.

\section{Results}

Table 1 shows the allele frequencies for each locus studied in the five screened Chibchan populations. All individuals sampled were YAP-. Four loci had the same allele as the modal in all the tribes: DYS $199 * T$, $\alpha$ h-II, $D Y S 19 * 13$, and $D Y S 389 A^{*} 17$. The allele frequency distributions of these four loci did not show statistical differences between the analyzed populations (exact test, $p>0.05$ ). On the other hand, variation at the DYS389B, DYS390, DYS391, and DYS393 loci did not show a predominant altele in all the tribes, and their allele frequency distributions were statistically different between the populations (exact test, $p<0.05$, applying a Bonferroni correction for multiple testing).

Table 2 shows the locus diversities for DYS19, DYS389A, DYS389B, DYS390, DYS391, and DYS393 in the sampled populations; they ranged from $0.322 \pm 0.060$ (DYS19) to $0.619 \pm 0.041$ (DYS390). The Huctar had the greatest average locus diversity $(0.506 \pm 0.046)$, whereas the Teribe showed the smallest $(0.242 \pm 0.078)$. The Chibchan average locus diversity was $0.434 \pm 0.059$.

The nine screened loci gave rise to $39 \mathrm{Y}$-chromosome haplotypes, grouped in two different haplogroups: the Q-M3 and the $Y^{*}$ (XYAP, M3) (Table 3). The microsatelite haplotype $13,17,11,23,10,13$ of the Q-M3 haplogroup was the most frequent haplotype $(0.183 \pm 0.040)$, found mainly in the Cabecar (15 out of 17) 
Table 1. Allele Frequencies at Eight Locj of the Y Chromosome in Five Chibchan Tribes of Lower Central America

\begin{tabular}{|c|c|c|c|c|c|c|}
\hline \multirow[b]{2}{*}{ Locus } & \multicolumn{4}{|c|}{ Tribe" } & & \multirow[b]{2}{*}{ Total (93) } \\
\hline & Bribri (14) & Cabecar $(28)$ & Guaymi (8) & Huetar (28) & Teribe (IS) & \\
\hline \multicolumn{7}{|l|}{ ah } \\
\hline 1 & $0.214 \pm 0.114$ & $0.071 \pm 0.050$ & $0.000 \pm 0.000$ & $0.000 \pm 0.000$ & $0.000 \pm 0.000$ & $0.054 \pm 0.024$ \\
\hline II & $0.786 \pm 0.114$ & $0.893=0.059$ & $1.000 \pm 0.000$ & $0.857 \pm 0.067$ & $1.000 \pm 0.000$ & $0.892 \pm 0.032$ \\
\hline III & $0.000 \pm 0.000$ & $0.036 \pm 0.036$ & $0.000 \pm 0.000$ & $0.107 \pm 0.060$ & $0.000 \pm 0.000$ & $0.043 \pm 0.02]$ \\
\hline IV & $0.000 \pm 0.000$ & $0.000 \pm 0.000$ & $0.000 \pm 0.000$ & $0.036 \pm 0.036$ & $0.000 \pm 0.000$ & $0.011 \pm 0.011$ \\
\hline \multicolumn{7}{|c|}{ DYS199 } \\
\hline $\mathrm{T}$ & $0.929 \pm 0.07 \downarrow$ & $0.821 \pm 0.074$ & $0.625 \pm 0.183$ & $0.643 \pm 0.092$ & $0.800 \pm 0.107$ & $0.763 \pm 0.044$ \\
\hline C & $0.071 \pm 0.071$ & $0.179 \pm 0.074$ & $0.375 \pm 0.183$ & $0.357 \pm 0.092$ & $0.200 \pm 0.107$ & $0.237 \pm 0.044$ \\
\hline \multicolumn{7}{|c|}{ DYS19 } \\
\hline 12 & $0.000 \pm 0.000$ & $0.036 \pm 0.036$ & $0.000 \pm 0.000$ & $0.036 \pm 0.036$ & $0.000 \pm 0.000$ & $0.022 \pm 0.015$ \\
\hline 13 & $1.000 \pm 0.000$ & $0.750 \pm 0.083$ & $1.000 \pm 0.000$ & $0.679 \pm 0.090$ & $0.933 \pm 0.067$ & $0.817 \pm 0.040$ \\
\hline 14 & $0.000 \pm 0.000$ & $0.107 \pm 0.060$ & $0.000 \pm 0.000$ & $0.214 \pm 0.079$ & $0.067 \pm 0.067$ & $0.108 \pm 0.032$ \\
\hline 15 & $0.000 \pm 0.000$ & $0.107 \pm 0.060$ & $0.000 \pm 0.000$ & $0.036 \pm 0.036$ & $0.000 \pm 0.000$ & $0.043 \pm 0.021$ \\
\hline 16 & $0.000 \pm 0.000$ & $0.000 \pm 0.000$ & $0.000 \pm 0.000$ & $0.036 \pm 0.036$ & $0.000 \pm 0.000$ & $0.011 \pm 0.011$ \\
\hline \multicolumn{7}{|c|}{ DYS389A } \\
\hline 15 & $0.071 \pm 0.071$ & $0.000 \pm 0.000$ & $0.375=0.183$ & $0.000 \pm 0.000$ & $0.000 \pm 0.000$ & $0.043 \pm 0.021$ \\
\hline 16 & $0.000 \pm 0.000$ & $0.036 \pm 0.036$ & $0.000 \pm 0.000$ & $0.286 \pm 0.087$ & $0.133 \pm 0.09 t$ & $0.118 \pm 0.034$ \\
\hline 17 & $0.714 \pm 0.125$ & $0.750 \pm 0.083$ & $0.500 \pm 0.189$ & $0.464 \pm 0,096$ & $0.600 \pm 0.131$ & $0.613 \pm 0.051$ \\
\hline 18 & $0.143 \pm 0.097$ & $0.143 \pm 0.067$ & $0.125 \pm 0.125$ & $0.071 \pm 0.050$ & $0.200 \pm 0.107$ & $0.129 \pm 0.035$ \\
\hline 19 & $0.071 \pm 0.071$ & $0.071 \pm 0.050$ & $0.000 \pm 0.000$ & $0.036 \pm 0.036$ & $0.067 \pm 0.067$ & $0.054 \pm 0.024$ \\
\hline 20 & $0.000 \pm 0.000$ & $0.000 \pm 0.000$ & $0.000 \pm 0.000$ & $0.143 \pm 0.067$ & $0.000 \pm 0.000$ & $0.043 \pm 0.021$ \\
\hline \multicolumn{7}{|c|}{ DYS389B } \\
\hline 9 & $0.000 \pm 0.000$ & $0.071 \pm 0.050$ & $0.000 \pm 0.000$ & $0.107 \pm 0.060$ & $0.000=0.000$ & $0.054 \pm 0.024$ \\
\hline 10 & $0.714 \pm 0.125$ & $0.357 \pm 0.092$ & $0.500 \pm 0.189$ & $0.464 \pm 0.096$ & $1.000 \pm 0.000$ & $0.559 \pm 0.052$ \\
\hline 11 & $0.286 \pm 0.125$ & $0.571 \pm 0.095$ & $0.500 \pm 0.189$ & $0.429 \pm 0.095$ & $0.000 \pm 0.000$ & $0.387 \pm 0.051$ \\
\hline
\end{tabular}


Table 1. (Continued)

\begin{tabular}{|c|c|c|c|c|c|c|}
\hline \multirow[b]{2}{*}{ Locks } & \multicolumn{6}{|c|}{ Tribe" } \\
\hline & Bribri (14) & Cabecar (28) & Guaymi (8) & Huetar (28) & Teribe (15) & Total (93) \\
\hline \multicolumn{7}{|c|}{$\overline{\text { DYS390d }}$} \\
\hline 21 & $0.000 \pm 0.000$ & $0.000 \pm 0.000$ & $0.000 \pm 0.000$ & $0.036 \pm 0.036$ & $0,000 \pm 0.000$ & $0.011 \pm 0.011$ \\
\hline 22 & $0.000 \pm 0.000$ & $0.071 \pm 0.050$ & $0.000 \pm 0.000$ & $0.107 \pm 0.060$ & $0.000 \pm 0.000$ & $0.054 \pm 0.024$ \\
\hline 23 & $0.286 \pm 0.125$ & $0.571 \pm 0.095$ & $0.000 \pm 0.000$ & $0.071 \pm 0.050$ & $0.000=0.000$ & $0.237 \pm 0.044$ \\
\hline 24 & $0.571 \pm 0.137$ & $0.321 \pm 0.090$ & $0.500 \pm 0.189$ & $0.643 \pm 0.092$ & $0.867 \pm 0.091$ & $0.559 \pm 0.052$ \\
\hline 25 & $0.071 \pm 0.071$ & $0.036 \pm 0.036$ & $0.500 \pm 0.189$ & $0.143 \pm 0.067$ & $0.133 \pm 0.091$ & $0.129 \pm 0.035$ \\
\hline 26 & $0.071 \pm 0.071$ & $0.000 \pm 0.000$ & $0.000 \pm 0.000$ & $0.000 \pm 0.000$ & $0.000 \pm 0.000$ & $0.011 \pm 0.011$ \\
\hline \multicolumn{7}{|c|}{ DY\$391" } \\
\hline 9 & $0.000 \pm 0.000$ & $0.000 \pm 0.000$ & $0.000 \pm 0.000$ & $0.000 \pm 0.000$ & $0.133 \pm 0.091$ & $0.022 \pm 0.015$ \\
\hline 10 & $0.929 \pm 0.071$ & $0.893 \pm 0.060$ & $0.125 \pm 0.125$ & $0.714 \pm 0.087$ & $0.733 \pm 0.118$ & $0.753 \pm 0.045$ \\
\hline 11 & $0.071 \pm 0.071$ & $0.036 \pm 0.036$ & $0.500 \pm 0.189$ & $0.214 \pm 0.079$ & $0.133 \pm 0.091$ & $0.151 \pm 0.037$ \\
\hline 12 & $0.000 \pm 0.000$ & $0.071 \pm 0.050$ & $0.375 \pm 0.183$ & $0.071 \pm 0.050$ & $0.000 \pm 0.000$ & $0.075 \pm 0.028$ \\
\hline \multicolumn{7}{|c|}{ DY $\$ 393^{\circ}$} \\
\hline 11 & $0.000 \pm 0.000$ & $0.000 \pm 0.000$ & $0.000 \pm 0.000$ & $0.036 \pm 0.036$ & $0.067=0.067$ & $0.022 \pm 0.015$ \\
\hline 12 & $0.000 \pm 0.000$ & $0.071 \pm 0.050$ & $0.500 \pm 0.189$ & $0.000 \pm 0.000$ & $0.000 \pm 0.000$ & $0.065 \pm 0.026$ \\
\hline 13 & $0.929 \pm 0.071$ & $0.857 \pm 0.067$ & $0.500 \pm 0.189$ & $0.679 \pm 0.090$ & $0.933 \pm 0.067$ & $0.796 \pm 0.042$ \\
\hline 14 & $0.071 \pm 0.071$ & $0.036 \pm 0.036$ & $0.000 \pm 0.000$ & $0.286 \pm 0.087$ & $0.000 \pm 0.000$ & $0.108 \pm 0.032$ \\
\hline 15 & $0.000 \pm 0.000$ & $0.036 \pm 0.036$ & $0.000 \pm 0.000$ & $0.000 \pm 0.000$ & $0.000 \pm 0.000$ & $0.011 \pm 0.011$ \\
\hline
\end{tabular}

a. Number of chromosomes for each tribe is given in parentheses.

b. $p<0.05$ by exact test of population differentiation.

c. $p<0.01$ by exact test of population differentiation.

d. $p<0.001$ by exact test of population differentiation. 
Table 2. Gene Diversities at Eight Loci of the Y Chromosome in Five Chibchan Tribes of Lower Central America

\begin{tabular}{|c|c|c|c|c|c|c|}
\hline \multirow[b]{2}{*}{ Locus } & \multicolumn{6}{|c|}{ Tribe } \\
\hline & Bribri(14) & Cabecar $(28)$ & Gucymi (8) & Huetar (28) & Teribe (15) & Total (93) \\
\hline DY\$199 & $0.143 \pm 0.119$ & $0.304 \pm 0.094$ & $0.536 \pm 0.124$ & $0.476 \pm 0.056$ & $0.343 \pm 0.128$ & $0.365 \pm 0.047$ \\
\hline$\alpha \mathrm{h}$ & $0.363 \pm 0.130$ & $0.203 \pm 0.097$ & $0.000 \pm 0.000$ & $0.257 \pm 0.097$ & $0.000 \pm 0.000$ & $0.201=0.054$ \\
\hline DYS19 & $0.000 \pm 0.000$ & $0.428 \pm 0.107$ & $0.000 \pm 0.000$ & $0.508 \pm 0.096$ & $0.134 \pm 0.113$ & $0.322 \pm 0.060$ \\
\hline DYS389A & $0.494 \pm 0.150$ & $0.426 \pm 0.107$ & $0.679 \pm 0.123$ & $0.701 \pm 0.060$ & $0.619 \pm 0.120$ & $0.593 \pm 0.053$ \\
\hline DY $\$ 389 B$ & $0.439 \pm 0.113$ & $0.561 \pm 0.060$ & $0.571 \pm 0.094$ & $0.6[1] \pm 0.046$ & $0.000 \pm 0.000$ & $0.541 \pm 0.028$ \\
\hline DY $\$ 390$ & $0.627 \pm 0.110$ & $0.585 \pm 0.069$ & $0.571 \pm 0.094$ & $0.568 \pm 0.099$ & $0.248 \pm 0.131$ & $0.619 \pm 0.041$ \\
\hline DY 5391 & $0.143 \pm 0.119$ & $0.203 \pm 0.098$ & $0.679 \pm 0.123$ & $0.455=0.094$ & $0.458 \pm 0.141$ & $0.408=0.057$ \\
\hline DY\$393 & $0.143 \pm 0.119$ & $0.268 \pm 0.107$ & $0.571 \pm 0.094$ & $0.474 \pm 0.079$ & $0.134 \pm 0.113$ & $0.354 \pm 0.060$ \\
\hline Average & $0.294 \pm 0.077$ & $0.372 \pm 0.053$ & $0.451 \neq 0.100$ & $0.506=0.046$ & $0.242 \pm 0.078$ & $0.434 \pm 0.059$ \\
\hline
\end{tabular}

a. Number of chromosomes for each tribe is given in parentheses. 
Table 3. Y-Chromosome Haplotypes Found in Five Chibchan Tribes of Lower Central America

$\begin{array}{lcccccccl}\alpha h & \text { DYSI99 } & \text { DYSI9 } & \text { DYS389A } & \text { DYS389B } & \text { DYS390 } & \text { DYS391 } & \text { DYS393 } & \text { Tribes }^{\text {b }} \\ \text { II } & \text { T } & 12 & 16 & 10 & 24 & 10 & 12 & \text { Cabecar (1) } \\ \text { II } & \text { T } & 12 & 17 & 11 & 24 & 10 & 13 & \text { Huetar (1) } \\ \text { II } & \text { T } & 13 & 17 & 10 & 23 & 10 & 13 & \text { Huetar (2) } \\ \text { II } & \text { T } & 13 & 17 & 10 & 24 & 10 & 13 & \text { Bribri (4), Cabecar (2). Teribe (8) } \\ \text { I (L) } & \text { T } & 13 & 17 & 10 & 24 & 10 & 13 & \text { Bribri (3) } \\ \text { II } & \text { T } & 13 & 17 & 10 & 24 & 11 & 13 & \text { Teribe (1) } \\ \text { II } & \text { T } & 13 & 17 & 11 & 23 & 10 & 13 & \text { Bribri (2), Cabecar (15) } \\ \text { II } & \text { T } & 13 & 17 & 11 & 24 & 10 & 13 & \text { Bribri (1), Huetar (5) } \\ \text { II } & \text { T } & 13 & 17 & 11 & 24 & 11 & 12 & \text { Guaymi (4) } \\ \text { II } & \text { T } & 13 & 17 & 11 & 25 & 10 & 13 & \text { Huetar (3) } \\ \text { II } & \text { T } & 13 & 18 & 10 & 23 & 10 & 12 & \text { Cabecar (1) } \\ \text { II } & \text { T } & 13 & 18 & 10 & 23 & 10 & 13 & \text { Bribri (1) } \\ \text { II } & \text { T } & 13 & 18 & 10 & 24 & 10 & 13 & \text { Cabecar (1), Teribe (1) } \\ \text { II } & \text { T } & 13 & 18 & 10 & 24 & 10 & 14 & \text { Huetar (1) } \\ \text { II } & \text { T } & 13 & 18 & 10 & 25 & 10 & 13 & \text { Guaymi (1), Teribe (1) } \\ \text { II } & \text { T } & 13 & 18 & 11 & 24 & 10 & 13 & \text { Huetar (1) } \\ \text { II } & \text { T } & 13 & 18 & 11 & 25 & 11 & 14 & \text { Bribri (1) } \\ \text { II } & \text { T } & 13 & 19 & 10 & 24 & 10 & 13 & \text { Cabecar (1) } \\ \text { II } & \text { T } & 13 & 19 & 10 & 24 & 10 & 14 & \text { Huetar (1) } \\ \text { II } & \text { T } & 13 & 19 & 10 & 25 & 10 & 13 & \text { Cabecar (1), Teribe (1) }\end{array}$




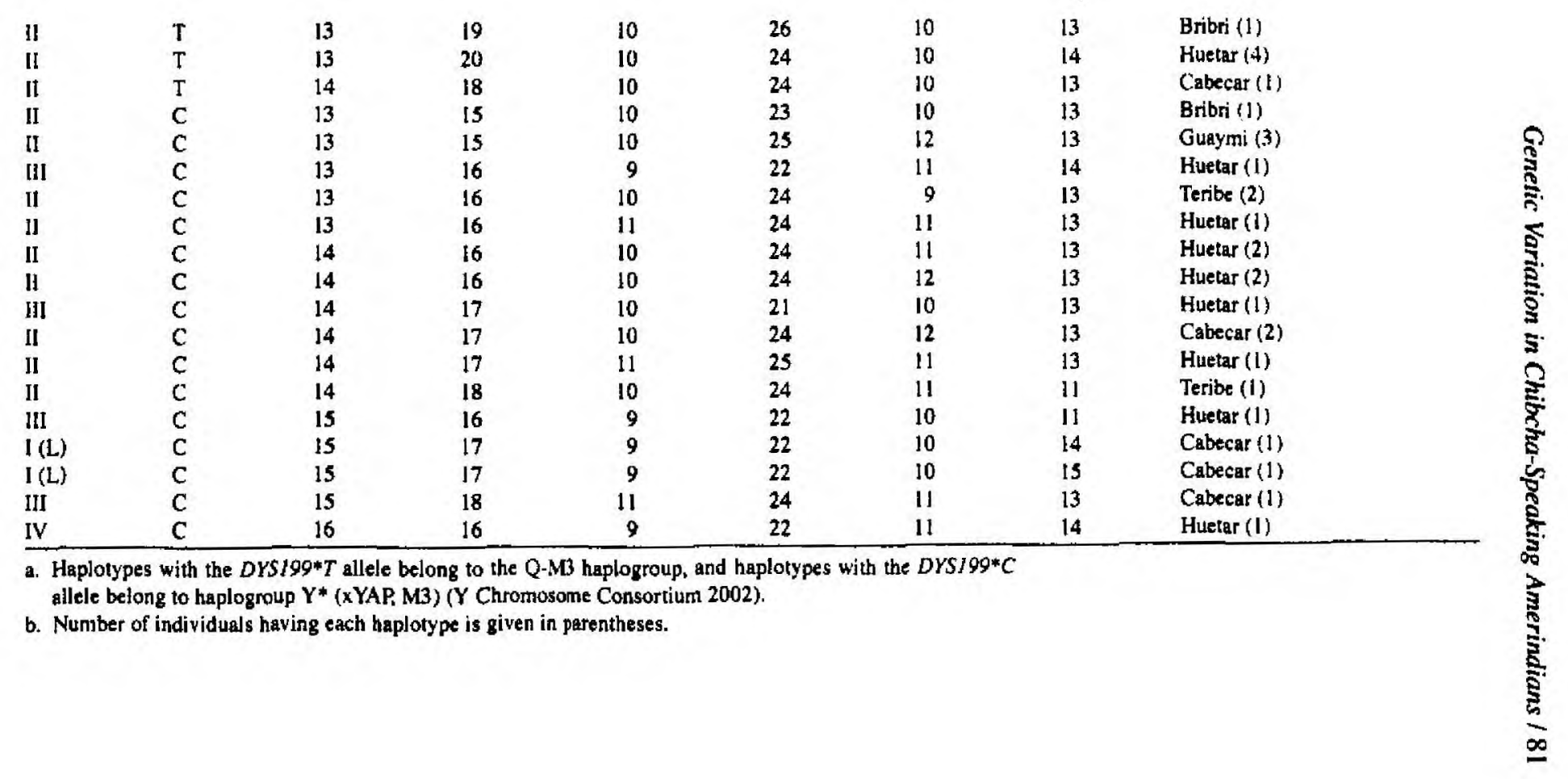


82 / RUIZ-NARVÁEZ ET AL..

Tatte 4. AMOVA of Eight Loci of the Y Chromosome in Five Chibchan Tribes of Lower Central America

\begin{tabular}{|c|c|c|}
\hline Locus & Variance $(\%)$ & $F_{S T}$ \\
\hline \multicolumn{3}{|l|}{ DYS $\$ 99$} \\
\hline Between populations & 2.62 & 0.026 \\
\hline Within populations & $97 \_38$ & \\
\hline \multicolumn{3}{|l|}{ ah } \\
\hline Between populations & 2.80 & 0.028 \\
\hline Within populations & 97.20 & \\
\hline \multicolumn{3}{|l|}{ DYSI9 } \\
\hline Between populations & 2.45 & 0.024 \\
\hline Within populations & 97.55 & \\
\hline \multicolumn{3}{|l|}{ DYS389A } \\
\hline Benweèn populations & 5.09 & $0.051^{*}$ \\
\hline Within populations & 94.91 & \\
\hline \multicolumn{3}{|l|}{ DYS389B } \\
\hline Between populations & 16.28 & $0.163^{c}$ \\
\hline Within populations & 83.72 & \\
\hline \multicolumn{3}{|l|}{ Drs390 } \\
\hline Between populations & 17.52 & $0.175^{c}$ \\
\hline Within populations & 82.48 & \\
\hline \multicolumn{3}{|l|}{ DYS391 } \\
\hline Between populations & 17.98 & $0.180^{\circ}$ \\
\hline Wilhin populations & 82.02 & \\
\hline \multicolumn{3}{|l|}{ DYS393 } \\
\hline Belween populations & 13.94 & $0.139^{\mathrm{b}}$ \\
\hline Within populations & 86.06 & \\
\hline
\end{tabular}

a. $p<0.05$ by random pertnutation lest.

b. $p<0.01$ by random permutation test.

c. $p<0,001$ by random permutation test.

and also in the Bribri (2 out of 17). Haplotype $13,17,10,24,10,13$ of the Q-M3 haplogroup, with a frequency of $0.151 \pm 0.037$, was present in three tribes: Bribri, Cabecar, and Teribe. An exact test of differentiation indicated that the haplotypes were not randomly distributed among the tribes ( $p<0.001)$. The estimated haplotype diversities were $0.890 \pm 0.060$ (Bribri), $0.717 \pm 0.094$ (Cabecar), $0.679 \pm 0.122$ (Guaymi), $0.942 \pm 0.025$ (Huetar), $0.724 \pm 0.121$ (Teribe), and $0.937 \pm 0.015$ (total).

For each marker only the $F_{S T}$ values were calculated, and they are shown in Table 4. The DYS199, ah, and DYS19 loci did not show $F_{S T}$ values statistically different from 0. On the other hand, DYS389A, DYS389B, DYS390, DYS391, and DYS393 had a significant differentiation between the populations, with DYS391 having the greatest heterogeneity $\left(F_{S T}=0.180\right)$. Using only the microsatellite loci, the average $F_{S T}$ value was 0.122 , which reduces to 0.034 when corrected to take into account the smaller effective size of $Y$ chromosomes compared to autosomes, according to Pérez-Lezaun et al. (1997). This value is half of the $F_{S T}$ value $(0.073)$ based on classical markers (Barrantes 1993a). 
Genetic Variation in Chibcha-Speaking Amerindians / 83

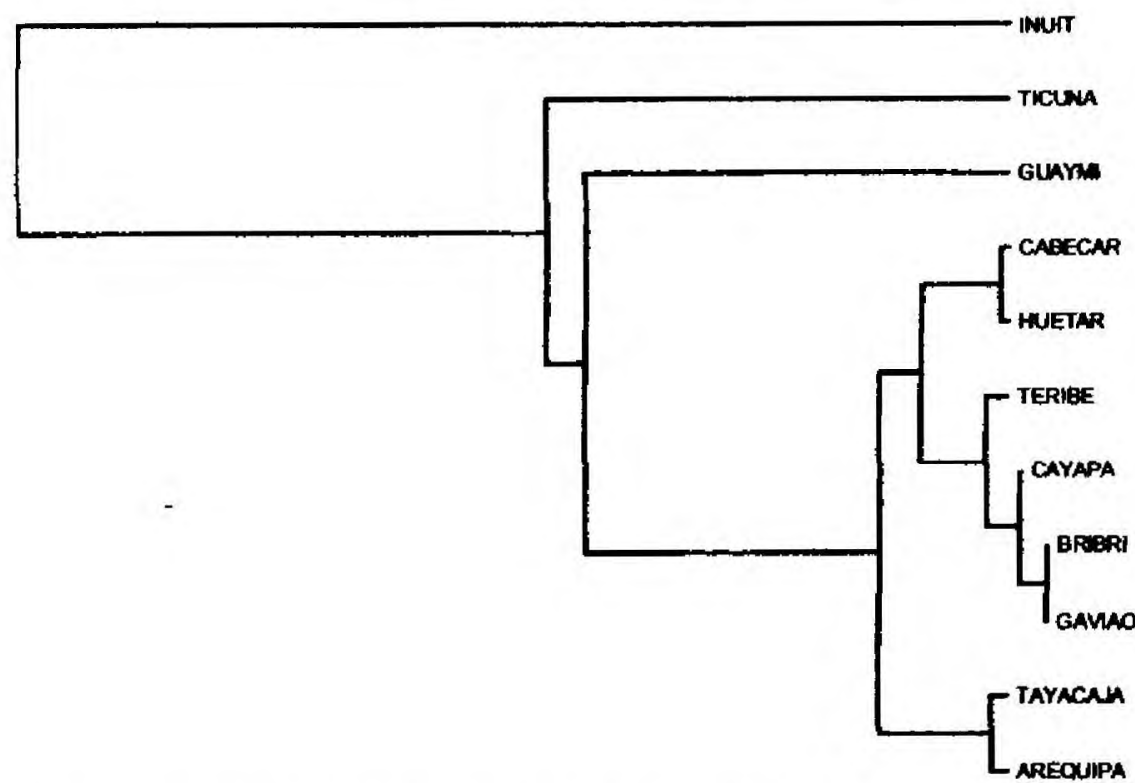

Figore 2 Neighbor-joining tree of five Chibchan tribes (Bribri, Cabecar, Guaymi, Huetar, and Teribe) of lower Central America, the Cayapa from Ecuador, the Tayacaja and Arequipa from the Ptruvian Andes, the Gaviao and Ticuna from Brazilian Amazonia, and the Inuit Irom the Arctic. Squared number of repeat differences among microsatellite haplotypes was used as genetic distance between tribes.

Considering only the haplotype frequencies, we obtained an $F_{s r}$ value of 0.183 (random permutation test, $p<0.001$ ). Using the number of differences among haplotypes, we estimated an $R_{S T}$ of 0.110 (random permutation test, $p<0.001$ ). The $F_{S T}$ value computed from mtDNA restriction data of six Chibchan tribes $(n=108)$ (Torroni et al. 1993, 1994) was 0.486. This estimate is almost three times the $F_{S T}$ calculated from $Y$-chromosome haplotypes. When the AMOVA was performed using only those tribes for which miDNA and $Y$ chromosome data can be matched (Bribri/Cabecar, Guaymi, and Teribe), we observed nonstatistically different $F_{S T}$ values of 0.228 and 0.190 , respectively.

Figure 2 shows a neighbor-joining tree, with squared number of repeal differences between haplotypes as genetic distance, of the five Chibchan populations, five Amerindian tribes of South America, and the Inuit from the Arctic. The neighbor-joining tree shows that all the Chibchan tribes, except the Guaymi, group together with the Cayapa from Ecuador and the Gaviao from Brazilian Amazonia. The two Andean populations (Tayacaja and Arequipa) formed a single group. The Inuit from the Arctic were the most divergent population compared to all the other tribes.

Figure 3 shows the mismatch distributions for the Y-chromosome and 
84 / RUIZ-NARVÁEZ ET AL.
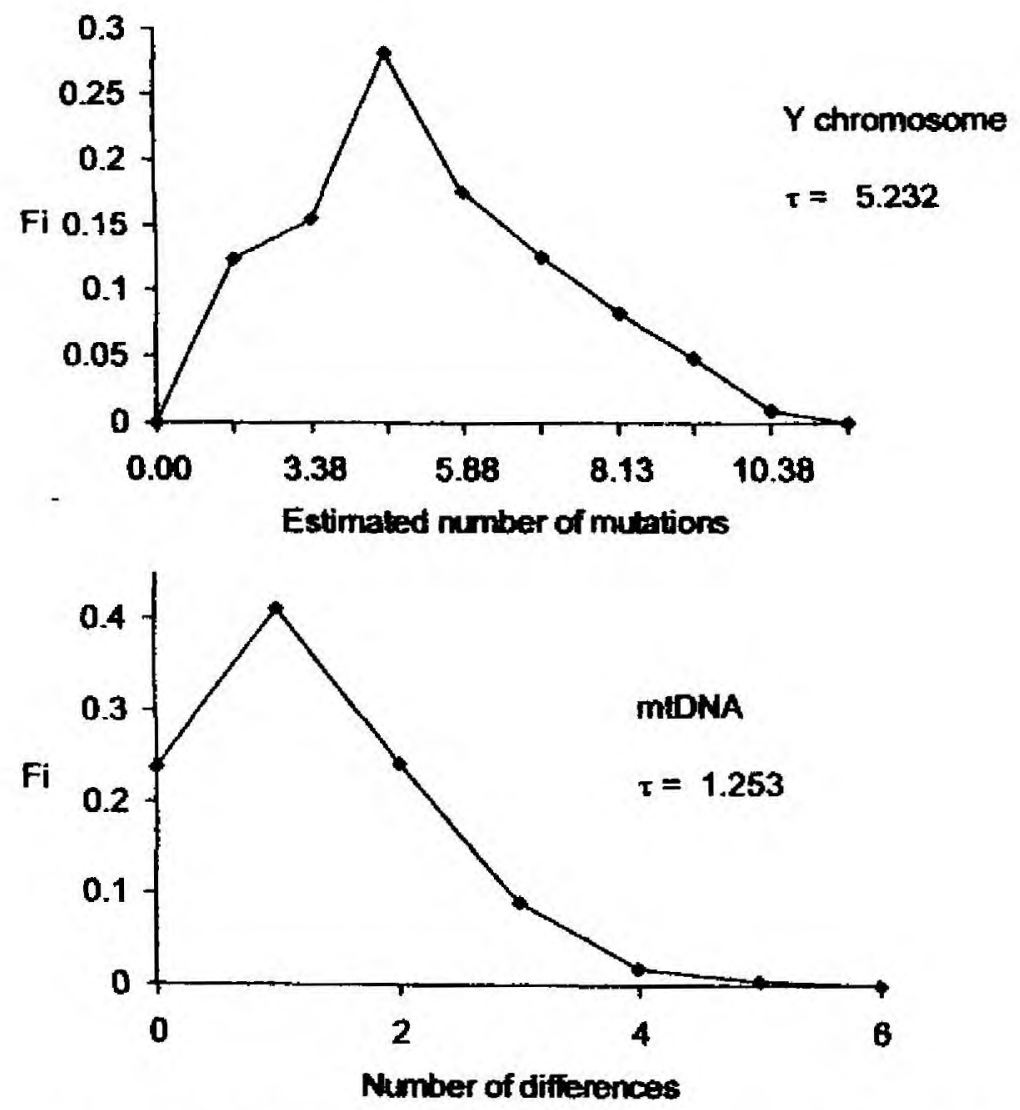

Figare 3. Mismatch distributions for the Y-chromosome microsatellites and mtDNA restriction

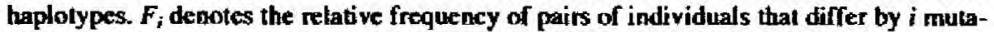
tions or restriction siles.

mtDNA restriction data. Only the $Y$ chromosomes of the $Q-M 3$ haplogroup were used, because the M3 genetic marker (allele DYS $199 * T$ ) is specific to native American poputations (Underhill et al. 1996). The estimates of the parameter $4 N_{e} \mu$ for each microsatellite were 0.341 for DYS19, 2.482 for DYS389A, 0.389 for DYS389B, 2.133 for DYS390, 0.300 for DYS391, and 0.955 for DYS393. An average of $4 N_{e} \mu=1.100$ was used to calculate the number of mutations between two individuals in the mismatch distribution.

Table 5 shows estimated coalescence times of the $Y$ chromosomes of the Q-M3 haplogroup and for mtDNA haplogroup A in Chibchan tribes. The $\tau$ estimator from the mismatch distribution gave older coalescence times compared to the $\Sigma d^{2}$ estimator. An average coalescence time of 3,113 years before present 
Table 5. Estimated Coalescence Times of the Y Chromosomes of the Q-M3 Haplogroup and miDNA Haplotypes of Haplogroup $A$ in Five Chibchan Tribes of Lower Central America

\begin{tabular}{|c|c|c|}
\hline & \multicolumn{2}{|c|}{ Coalescence Time (Years) (9S\% Cl) } \\
\hline & $\mu_{1}=1.90 \times 10^{-2}$ per Generation" & $\mu_{1}=4.14 \times 10^{-3}$ per Generation ${ }^{h}$ \\
\hline \multicolumn{3}{|l|}{ Y chromosorne } \\
\hline$t=5.232^{2}$ & $3,713(1,667-8,267)$ & $15,797(2,782-89,680)$ \\
\hline$\sum d^{2}=3.540^{\prime}$ & $2,513(1,129-5,585)$ & $10,668(1,880-60,776)$ \\
\hline \multirow[t]{2}{*}{ Avernge } & $3.113(1,400-6.919)$ & $13.243(2,326-75,358)$ \\
\hline & $\mu_{1}=2.27 \times 10^{-3}$ per Generation ${ }^{c}$ & $\mu_{1}=1.72 \times 10^{-3}$ per Generation \\
\hline $\mathrm{mtDNA}, \tau=1.253$ & $7,452(3,102-17,890)$ & $9,834(3.805-25,438)$ \\
\hline
\end{tabular}

a. Total mutation rate estimated as 6 loci $\times\left(3.17 \times 10^{-3}\right.$ per locus per generation) based on Kayser et al. (2000).

b. Total mutation rate estimated as 6 loci $\times\left(6.90 \times 10^{-1}\right.$ per locus per generation) based on Zhivotovsky et al. (2004).

c. Total mutation rate equivalent to a divergence rate of $0.029 \%$ per nucleotide per 10,000 years (Torroni el al. 1994).

d. Total mutation rate equivalent to a divergence rate of $0.022 \%$ per nucleotide per 10,000 years (Torroni el al. 1994).

e. $\tau$ estimator from the mismatch distribution, which is equivalent to the expected number of mutations between two randomly sampled haplotypes.

r. Total squared difference in allele size between two randomly sampled haplotypes.

$(95 \% \mathrm{Cl}=1,400$ to 6,919$)$ was estimated using a mutation rate of $3.17 \times 10^{-3}$ per locus per generation (Kayser et al. 2000); the average coalescence time was 13,243 years before present $(95 \% \mathrm{CI}=2,326$ to 75,358 ) when an effective mutation rate of $6.90 \times 10^{-4}$ per locus per generation was used (Zhivotovsky et al. 2004). On the other hand, the mismatch distribution for mIDNA haplogroup $A$ is also unimodal, which is compatible with coalescence times of 7,452 years before present $(95 \% \mathrm{CI}=3,102$ to 17,890$)$ using a total mutation rate of $2.27 \times 10^{-3}$ per generation and 9,834 years before present $(95 \% \mathrm{Cl}=3,805$ to 25,438 ) using a total mutation rate of $1.72 \times 10^{-3}$ per generation (Torroni et al. 1994).

\section{Discussion}

The survey of genetic variation along the $Y$ chromosome in five Chibchan tribes of Costa Rica and Panama showed that, according to both gene and haplotype diversities, the Huetar are the most diverse group. The Huetar also have the highest value of European and African admixture among the Chibchan tribes of Costa Rica and Panama (Barrantes 1993a), and the greatest diversity of the $Y$ chromosome is likely related to this fact, because most of the European contribution to the Costa Rican gene poof was male mediated. Although the samples 
86 / RUIZ-NARVÁEZ ET AL.

were selected to minimize the effects of the admixture with non-Amerindians, an absolute depuration cannot be guaranteed. Thus it is highly possible that a remnant of interethnic admixture was disclosed by the loci screened.

The AMOVA showed that the genetic variation of the $Y$ chromosome within tribes was greater than the genetic variation between tribes. An average $F_{S T}$ value of 0.122 based on the six microsatellite loci was oblained, which reduces to 0.034 when it is corrected to take into account the smaller effective size of $\mathrm{Y}$ chromosomes compared to autosomes (Pérez-Lezaun et al. 1997). This value is half the $F_{S T}$ value of 0.073 based on classical autosomal markers (Barrantes 1993a). Although these results suggest that, after correction for effective size, the differentiation of $\mathrm{Y}$ chromosomes is smaller than the differentiation of classical autosomal markers among Chibchan tribes, some caution is needed. By restricting our analysis to the Q-M3 haplogroup, we estimated an $F_{S T}$ value of 0.218 , and after correction for the smaller effective size of $Y$ chromosomes, the $F_{S T}$ value obtained for the Q-M3 haplogroup bocame 0.065 , in closer agreement with the $F_{S T}$ value based on classical autosomal markers. A more plausible conclusion is to assert that Y-chromosome and autosomal markers have the same degree of structuring among Chibchan tribes. Although this conclusion differs from the observed worldwide structure, where $Y$ chromosomes tend to show a higher stratification than autosomal markers do, the same pattem has been noted in at least two other human populations. Pérez-Lezaun et al. (1997) found the same degree of structure using either eight microsatellites in the $Y$ chromosome $\left(F_{S T}=0.0098\right)$ or 20 autosomal microsatellites $\left(F_{S T}=0.0100\right)$ in Catalans and Basques from the Iberian Peninsula.

The lack of differential structuring of the Chibchan populations, for maternally (mtDNA, $F_{S T}=0.228$ ) and paternally (Y chromosome, $F_{S T}=0.190$ ) inherited haplotypes, is noteworthy. This finding is remarkable because previous comparisons in other populations indicated that $\mathbf{Y}$-chromosome haplotypes are more geographically clustered than mtDNA haplotypes (Ruiz-Linares et al. 1996; Pérez-Lezaun et al. 1999), perhaps because women move more often to find partners (Cavalli-Sforza 1998; Pérez-Lezaun et al. 1999). Because our samples were selected with the goal of minimizing the effects of European and African genetic infiltration over the past $\mathbf{5 0 0}$ years, it is possible that selection bias might affect our results. However, we think that bias resulting from sample selection cannot completely explain our data. First, an equal population structure of both mtDNA and $\mathrm{Y}$ chromosomes is supported by ethnological data, which show that estimated marital distances are small in these tribes, ranging between $2 \mathbf{~ k m}$ and $13 \mathrm{~km}$. Also $76 \%$ of the unions happen within the same locality, and there are no differences between the migration rates of males and females in these populations (Barrantes 1993b). Last, the recent study by Bortolini et al. (2002) did not find differences in the degree of population structure between mtDNA RFLPs and Ychromosome biallelic markers in Amerindians from North, Central, and South America, supporting our conclusion of equal migration rates of males and females among Chibchan populations. 
Two Y-chromosome haplotypes of the Q-M3 haplogroup $(13,17,11,23$, $10,13$ and $13,17,10,24,10,13)$ were found in one-third of the samples. The $13,17,10,24,10,13$ haplotype was found in three of the five populations studied, and the $13,17,11,23,10,13$ haplotype was found in only two of them. In addition, most of the individuals with the $13,17,11,23,10,13$ haplotype ( 15 out of 17 ) were Cabecars from Alto Telire (see Figure 1). This population has a high inbreeding coefficient, and it was founded by only a few persons (J. Azofeifa, unpublished data. 1998). Therefore the $13,17,11,23,10,13$ haplotype, despite its high frequency, is not a good candidate to be considered a Y-chromosome founder haplotype of the Chibcha. It is noteworthy that the $13,17,11,23,10,13$ haplotype was not found in the survey of 95 Amerindian males of North and South America (Carvalho-Silva et al. 1999).

On the other hand, the high frequency and wider distribution of the $13,17,10,24,10,13$ haplotype make it a better candidate. This haplotype is not specific to the Chibchan group, and it has also been found in other native American populations (Bianchi et al. 1998; Carvalho-Silva et al. 1999) and seems to be a major $\mathrm{Y}$-chromosome founder haplotype of Amerindian populations, as postulated elsewhere (Pena et al. 1995; F. R. Santos et al. 1995a, 1996). Using only the $Y$ chromosomes of the Q-M3 haplogroup, we found that the $13,17,10,24,10,13$ haplotype has a frequency of $5.7 \%$ in a sample of linguistically diverse native Americans (Bianchi et al. 1998) and a frequency of $19.7 \%$ in the Chibchan populations (this study). This increment could be the joint result of genetic drift and a bottleneck at the Chibchan origin. It is noteworthy that the Chibcha show smaller mtDNA diversity than other Amerindian groups (M. Santos et al. 1994; Kolman et al. 1995), perhaps associated with a bottleneck at the separation of the ancestral proto-Chibcha from other Amerindian populations (Kolman et al. 1995).

The estimated coalescence times of the $Y$ chromosome roughly agree with the proposed time of origin of the Chibchan group at 7,000-10,000 years before present (Barrantes et al. 1990; Constenla-Umaña 1991; Kolman et al. 1995). As expected, the estimated coalescence times are greatly dependent on the chosen mutation rates. A more than fourfold deviation (approximately 10,000 years) was observed between the average coalescence times by using two different estimates of the mutation rate of the Y-chromosome microsatellites. The effective mutation rate (Zhivotovsky et al. 2004) has several drawbacks that must be taken into account when interpreting estimated coalescence times. First, the effective mutation rate is based on current variation, and reverse mutations will tend to reduce the standing number of aheles, leading to an underestimate of the tnue mutation rate. Also, differential selection among haplotypes (Jobling and Tyler-Smith 2000) may bias the estimated coalescence times. Last, the high standard deviation across loci compared to the mean effective mutation rate produced very wide 95\% confidence intervals of the estimated coalescence times, with an average upper limit of approximately 75,000 years before present. Because of these limitations, we think that the use of a mutation rate estimated from father-son pairs 


\section{8 / RUIZ-NARVÁEZ ET AL.}

(Kayser et al. 2000) is a more reliable approach; father-son pairs have the advantage of producing a tighter $95 \%$ confidence interval $(1,400-6,919$ years before present).

We used two different estimators of the coalescence time: the $\tau$ estimator from the mismatch distribution and the total squared differences in allele size ( $\Sigma d^{2}$ estimator). In general, the $\tau$ estimator produced older coalescence times relative to the squared differences estimator. The latter might underestimate the coalescence time because it does not take into account the effective size of the population. In our sample, only two haplotypes $(13,17,10,24,10,13$ and $13,17,11,23,10,13$ ) add up to $43.7 \%$ of the $Y$ chromosomes of the Q-M3 haplogroup. When the squared differences in allele size are calculated for all the $Y$-chromosome pairs, there are many pairs with 0 differences. Therefore the average squared difference underestimates the coalescence time of all the $Y$ chromosomes of the sample. The use of the parameter $4 N_{e} \mu$ corrected this bias, because within a population the estimated time of divergence between two chromosomes depends on the difference of allele size, the effective size of the population, and the mutation rate.

The approach used to estimate the number of mutations between two $Y$ chromosomes supposes a steady-state distribution of the allele sizes; in other words, it assumes that the distribution of the allele sizes fits the expectation under a stepwise mutation model, and the frequency distribution of all six microsatellites fitted a single-step mutation model (data not shown). Estimated coalescence times from mtDNA data (7,452 and 9,834 years before present) roughly agree with the estimate from the $Y$-chromosome data $(3,113$ and 13,243 years before present). It might be argued that microsatellite loci and RFLP polymorphisms evolve at very different rates and thus that any comparison between Y-chromosome and mtDNA data would be meaningless. However, although the coalescence times are expressed in mutational units $\left(\tau / 2 \mu_{3}\right)$, they are corrected according to the mutational rates of each genetic system. Last, it must be pointed out that all the estimates from both Y-chromosome and mtDNA data (see Table 5 for confidence intervals) are compatible with a Chibchan origin of approximately 6,000 years before present, which was estimated using classical markers (Barrantes et al. 1990), linguistic data (Constenla-Umaña 1991), and archeological data (Cooke and Ranere 1992).

Acknowledgments We thank E. Tarazona for his help during the course of this study. This research was supported by the Vicerrectoría de Investigación, Universidad de Costa Rica, through grant 742-90-416, and by the Consejo Nacional de lnvestigaciones Científicas y Tecnológicas de Costa Rica (CONICTT), through grant 196-10. E. Ruiz was also supported by the Thind World Academy of Sciences (UNESCOTTWAS), under contract SC/RP 206.039.7.

Received 13 February 2004; revision received 9 August 2004. 
Genetic Variation in Chibcha-Speaking Amerindians / 89

\section{Literature Cited}

Abel, S. 1981. Berween Continents/Between Seas: Pre-Columbian Art of Costa Rica. New York: Abrams.

Barrantes. R. 1993a Diversidad genética y mezcla racial en los amerindios de Costa Rica y Panamá. Rev. Biol. Trop. 41:379-384.

Barrantes, R. 1993b. Enolución en el trópico: Los amerindias de Coska Rica y Panama. San José. Costa Rica: Editorial de la Universidad de Costa Rica.

Barrantes, R., P. E. Smouse, H. W. Mohrenweiset et al. 1990. Micsoevolution in lower Central America: Genetic characterization of the Chibcha-speaking groups of Costa Rica and Panama, and a consensus taxonomy based on genetic and linguistic affinity. Am. J. Hum. Genet. 46:63-84.

Bianchi, N. O., C. I, Catanesi, G. Bailliet et al. 1998. Characterization of ancestral and derived Ychromosome haplotypes of New Word Native populations. Am. J. Hun. Genet. 63:1,8621.871 .

Bortolini, M. C., F. M. Salzano, C. H. Bau et al. 2002. Y-chromosome biallelic polymorphisms and Native American population stnucture. Ann. Hum. Genet. 66:255-259.

Carvalho-Silva, D., F. R. Santos, M. H. Hutz et al. 1999. Divergent human Y-chromosone microsa. tellite evolution rates. J. Mol. Evol, 49:204-214.

Cavalli-Sforza, L L 1998. The DNA revolution in population genetics. Tr. Gener. 14:60-65.

Chakraborty, R., and M. Nei. 1976. Hidden genetic variability within electromorphs in finite populations. Gemetics 84:385-393.

Constenla Umaña, A. 1991. Las lenguas del Area Intermedia: Introducción a su estudio areal. San José, Costa Rica: Editorial de la Universidad de Costa Rica.

Cooke, R., and A. J. Ranere. 1992. The origin of wealth and hitrarchy in the central region of Panama (12,000-2,000 B.P), with observations on its retevance to the bistory and phylogeny of Chib cha-speaking polities in Panama and elsewhere. In Wealth and Hierarchy in the Intermediate Area, F. W. Lange, ed. Washinglon, DC: Dumbarton Oaks Research Library Collection, 243315.

Excoffier, L., P. E. Smouse, and J. M. Quattro. 1992. Analysis of molecular variance inferred from metric distance among DNA haplotypes: Application to human mitochondrial DNA restriction data. Genetics 131:479 491.

Felsenstein, J. 1995. PHYUP: Phylogeny Inference Package Version 3.57c, Seattle: University of Washington.

Freije, D., C. Helms, M. S. Watson et al. 1992. Identification of a second pseudoautosomal region near the $\mathrm{Xq}$ and $\mathrm{Yq}_{q}$ telomerts. Science 258:1,784-1,787.

Goldstein. D. B., A. Ruiz-Linares, 1. 1. Cavalti-Sforza et al. 1995. An evaluation of genetic distances for use with microsateilite loci. Genetics 139:463-47!.

Greenberg. 1. H. 1987. Language in the Americas. Stanford, CA: Stanford University Press.

Hammer, M. F., and S. Horaj, 1995. Y-chromosomal DNA variation and the peopling of Japan. Am. J. Hum. Genet. 56:951-962.

Hermann, B. G., and A. M. Frischauf. 1987. Isolation of genomic DNA. Mesh. Enzymol. 152:180183.

Jobling, M. A., and C. Tyier-Smith. 1995. Father and sons: The $\mathrm{Y}$ chromosome and buman evolution. Tr. Gener, 11:449-456.

Jobling, M. A., and C. Tyler-Smith. 2000. New uses for new haplotypes: The human Y chromosome, disease, and selection. Tr. Genet. 16:356-362.

Karafet, T. M., S. L. Zegura, O. Posukh et al. 1999. Ancestral Asian source(s) of New World Ychromosome founder haplotypes. Am. J. flwn. Genet. 64:817-831.

Kayser, M., A. Caglià, D. Corach et al. 1997. Evaluation of Y-chromosomal STRs: A multicenter study. Int. J. Legal Med, 110-125-133. 


\section{0 / RUIZ-NARVÁEZ et AL.}

Kayser, M., M. Krawczak, L Excoffier et al. 200I. An extensive analysis of Y-chromosomal microsatellike haplotypes in globally dispersed buman populations. Am. J. Hum. Genet. 68:9901,018 .

Kayser, M., L. Roewer, M. Hedenan et al. 2000. Characteristics and frequency of germline mutations at microsalellite loci from the hurran $Y$ chromosome, as revealed by direct otwervation in father/son pairs. Am. J. Hum. Genet. 66:1,580-1,588.

Kimura, M., and J. Crow. 1964. The number of alleles that can be maintained in a finite population. Genesics 49:725-738.

Kolman, C. J.. E Bermingham, R. Cooke et al. 1995. Reduced mtDNA diversity in the Ngübe Amerinds of Panama Genetics 140:275-283.

Miller, S. A. D. D. Dykes, and H. F. Polesky. 1988 . A simple salting-out procedure for exiracting DNA from human nucleated cells. Nucleic Acids Res. 16:1,215.

Maller, U., and W. Schempp. 1982. Homologous early replication patterns of the distal short arms of prometaphasic $X$ and $Y$ chromosomes. Hum. Genet. 60:274-275.

Neel, J. V., and K. M. Weiss. 1975. The genetic structure of a tribal population, the Yanomama Indians. XII. Biodemognaphic studies. Am. J. Phys. Anthropol. 42:25-5I.

Nei. M., and F. Tajima. 1981. DNA polymorphism delectablc by restriction endonucleases. Genefics 97:145-163.

Nielsen, R. 1997. A likelihood approach to population samples of microsatellite alkeles, Generics 146:711-716.

Ohta, T., and M. Kimura. 1973. A model of mutation appropriate to estimate the number of electro phoretically detectable alteles in a finite population. Geret. Res. 22:201-204.

Pena, S. D., F: R. Santos, N. Bianchi et al. 1995. A major founder Y-chromosome haplotype in Amerindians. Nat. Genet. 11:15-16.

Pérez-Lezaun, A., F. Calafell, D. Combas et al. 1999. Sex-specific migration pallems in Central Asian populations, nevealed by analysis of Y-chromosome short tandem repeats and miDNA. Am. J. Hum. Genet. 65:208-219.

Pérez-Lezaun, A., F. Calafell, M. Seielstad et al. 1997. Population genetics of Y-chromosome short tandem repeats in humans. J. Mol. Evol. 45:265-270.

Raymord, M., and F. Rousset. 1995. An exact test for poptlation differentiation. Evolution 49:1,2801,283 .

Rogers, A. R. 1995. Genetic evidence for a Pleistocene population explosion. Evolution 49:608-615.

Rogers. A. R., and H. Happending. I992. Population growth makes waves in the distribution of pairwise genetic differences. Mol. Biol. Evol. 9.552-569.

Ruiz-Linares, A., K. Nayar, D. B. Goldstein el al. 1996. Geographic clustering of hurnan Y-chromosome haplotypes. Ann. Hum. Genet. 60:401 -408.

Saitou, N., and M. Nei. 1987. The neighbor-joining method: A new method for reconstructing phylogenetic trees. Mol. Biol. Evol. 4:406-425.

Santos, F. R., M. H. Hutz, C. E. Coimbra et al. 1995a Further evidence for the existence of a major founder Y chromosome baptotype in Amerindians. Brazil. J. Genet. 18:669-672.

Santos, F. R., A. Pandya, C. Tyler-Smith et al. 1999. The Central Siberian origin for Native American Y chromosomes. Am. J. Hum. Genet, 64:619-628.

Santos, F. R., S. D. Pena, and C. Tyler-Smith. 1995b. PCR haplotypes for the human Y chromosome based on alphoid satelitite DNA variants and heteroduplex analysis. Gere 165:191-198.

Santos, F R. L. Rodriguez-Delfín, S. D. Pena et at. 1996. North and South Amerindians may have the same major founder $Y$ chromosome haplotype. Am. J. Hum. Genet. 58:1,369-1,370.

Santos, M., R. H. Ward, and R. Barrantes. 1994. mtDNA variation in the Chibcha Amerindian Huetar from Costa Rice Hum. Biol. 66:963-977.

Schneider, S., J. M. Kueffer, D. Roesli et al. 1997. Arlequin Version I.I: A Software for Population Genetic Data Analysis. Geneva: University of Geneva.

Slatkin, M. 1995. A measure of population subdivision based on microsatellite allele frequencies. Genetics 139:457-462. 
Genetic Variation in Chibcha-Speaking Amerindians / 91

Tarazona-Santos, E. D. R. Carvalho-Silva, D. Pettener el al. 2001. Genetic differentiation in South Amerindians is jelated to environmental and cuttural diversity: Evidence from the $Y$ chromosome. Am. J. Hum. Genet. 68:1,485-1,496.

Torroni, A., J. V. Neel, R. Barrantes et al. 1994. Mitochondrial DNA -clock" for the Amerinds and its implications for timing their entry into North America. Proc. Natl. Acad. Sci. USA $91: 1,158-1,162$.

Torroni, A., T. G. Schurr, M. F. Cabell el al. 1993. Asian affinitics and continental radiation of the four founding Native American miDNAs. Am. J. Hum. Genet. 53:563-590.

Underhill, P. A., L. Jin, R. Zemans te al. 1996. A pre-Columbian Y-chromosome-specific transition and its implications for humban evolutionary history. Proc. Natl. Acad. Sci. USA 93:196-200.

$Y$ Chromosome Consortium. 2002. A nomenclature system for the tree of human Y-ehromosomal binary haplogroups. Genome Res. 12:339-348.

Zhivotovsky, L. A., P. A. Underhill, C. Cinnioglu et al. 2004. The effective mutation rale at $Y$ chromosome short tandem repeats, with application to human population-divergence time. Am. J.HIwn. Gener. 74:50-61. 